\title{
Histological and electron microscopic study on Macrobra- chium muscle virus (MMV) infection in the giant freshwater prawn, Macrobrachium rosenbergif (de Man), cultured in Taiwan
}

\author{
C W Tung, C S Wang and S N Chen \\ Department of Zoology, National Taiwan University, Taipei, Taiwan
}

The giant freshwater prawn, Macrobrachium rosenbergii (de Man), has been one of the major aquacultural products of Taiwan for the past decade. The annual production of cultured freshwater prawns increased from 1477 MT in 1982 to 16196 MT in 1991, and in recent years, these animals have become the second most important cultured crustacean crop after the marine prawn, Penaeus monodon (Fabricius). Since 1992, the postlarvae of freshwater prawns in southern Taiwan have been affected by an epizootic disease similar to idiopathic muscle necrosis (IMN) syndrome (Akiyama, Brock \& Haley 1982; Anderson, Nash \& Shariff 1990b). The affected prawns exhibit white opaque areas in abdominal segments, commonly accompanied by progressive weakening of their feeding and swimming ability. The histopathological changes are similar to those of IMN syndrome, as described by previous studies (Nash, Chinabut \& Limsuwan 1987). Unlike IMN, a cytoplasmic inclusion body has also been detected in the necrotic muscle of diseased prawns. Electron microscopy revealed icosahedral virus particles in the cytoplasm of necrotic cells as well as aggregations of viral particles in the inclusion body. The virus is temporarily named Macrobrachium muscle virus (MMV) until its taxonomical position is

Correspondence Professor S N Chen, Department of Zoology, National Taiwan University, Taipei, Taiwan 106.

E-mail:snchen@ms.cc.ntu.edu.tw ascertained by analysing the structure of the genomic DNA. The present paper discusses the first histopathological and ultrastructural observation of MMV infection in cultured freshwater prawn postlarvae from Taiwan.

Postlarvae of freshwater prawns (0.02-0.08 g) were collected for the present study from Pington in southern Taiwan. All histological processing and staining followed the standard procedures, as described by Bell \& Lightner (1988). Sections were stained using haematoxylin and eosin (H\&E), Feulgen reaction, Pyronin methyl green (Kurnick 1952) and acridine orange stain.

The diseased prawns selected for transmission electron microscopic studies were dissected and preserved in $2.5 \%$ phosphate-buffered glutaraldehyde with $1 \%$ tannic acid at $4{ }^{\circ} \mathrm{C}$ for $1 \mathrm{~h}$. After several rinses with buffered solution, the sample materials were postfixed with $1 \% \mathrm{O}_{\mathrm{S}} \mathrm{O}_{4}$ for $1 \mathrm{~h}$. The tissues were dehydrated under ethanol series and embedded in Spurr's resin. Ultra-thin sections were cut with an ultratome (Sorvall MT-5000, DuPont, Newtown, CT, USA), stained with uranyl acetate and lead citrate, and observed using a transmission electron microscope (Hitachi H-600, Hitachi, Japan) at $75 \mathrm{kV}$.

Giant freshwater prawns affected by MMV disease were found throughout the year in Taiwan. In most cases, outbreaks of the disease occurred between July and December within 10 days of moving postlarvae to outdoor ponds. Moribund prawns grossly exhibited non-transparent muscle in 


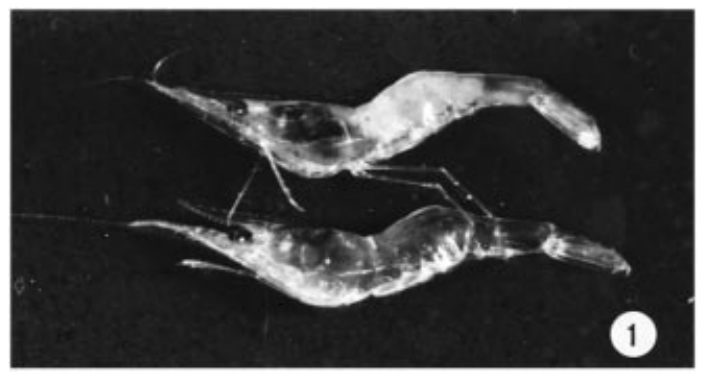

Figure 1 External appearance of giant freshwater prawn infected with Macrobrachium muscle virus. Note the opaque muscle in the body of the diseased prawn (upper) and the transparent muscle in the body of the normal prawn (lower).

abdominal segments 2-6 (Fig. 1). The affected prawns commonly displayed progressively weakened swimming ability, and an inclination to stay on vegetation or the pond bank. The mortalities of diseased prawns reached between $\approx 50 \%$ and $70 \%$ within 2 weeks after transferring the postlarvae to the grow-out ponds.

The occurrence of MMV appears not to be correlated with the biotic and abiotic factors often associated with IMN. Idiopathic muscle necrosis has been associated with predisposing environmen-

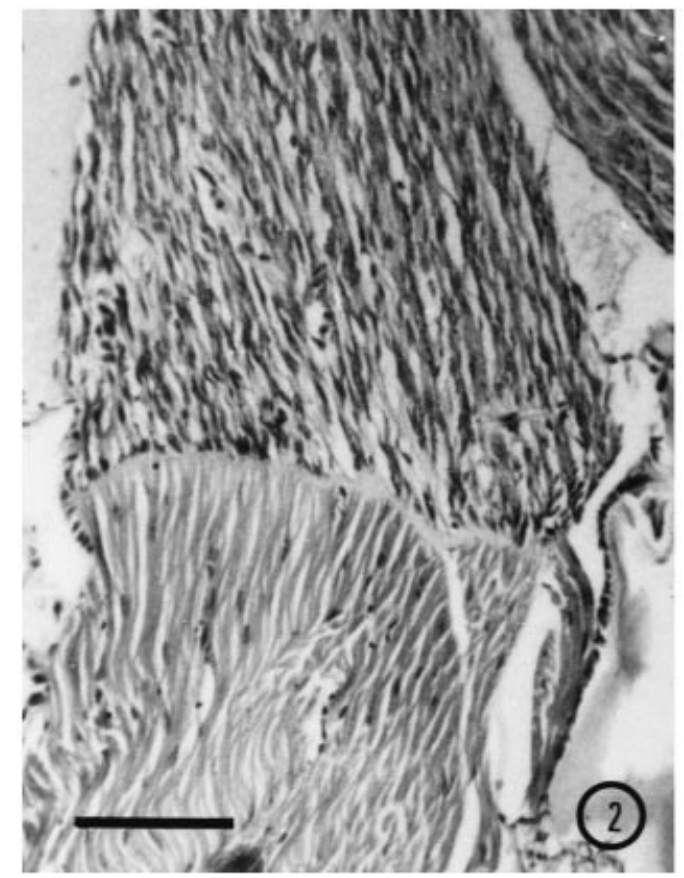

tal stressors including extremes and sudden fluctuations in salinity, temperature, hyperactivity, high concentrations of quinaldine, overcrowding, exposure to direct sunlight, physical handling and exposure to air (Nash et al. 1987). Water quality, as measured by ammonia, nitrate, COD and gross bacteria, in the infected southern Taiwan ponds did not differ from the non-infected ponds (data not shown). Furthermore, microscopic observation revealed no epibiotic organisms on either healthy or MMV-affected prawns.

The results of the histopathological study of affected prawns generally included progressive segmental myofibre degeneration of muscle fibres and necrobiotic myopathy. More specific features included eosinophilia or hyalinization, fragmentation, flocculation, granulation, and haemocyte infiltration (Fig. 2). It was also noted that the prominent shrinkage of the myofibres caused by progressive loss of parenchyma (myofibrils and sarcoplasm) led to diffuse areas of myofibre disorganization. The latter was associated with numerous single, rows, aggregations and/or sheets of hyperchromatic myonuclei, often centrally or eccentrically placed (nuclear internalization), and pyknotic nuclei. However, no bacteria, fungi or

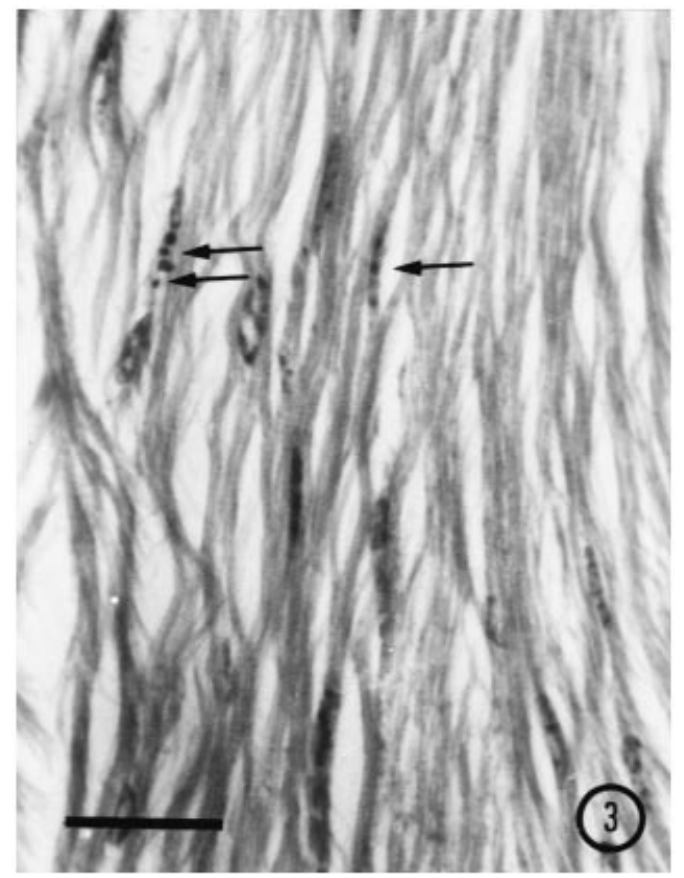

Figures $2 \& 3$ Photomicrographs of muscle tissue from giant freshwater prawn infected with Macrobrachium muscle virus: (2) the upper and lower areas show severe diffuse myofibre necrosis displaying a multitude of elongated nuclei and multifocal haemocyte infiltration, and normal muscle, respectively $(\mathrm{H} \& \mathrm{E}$, bar $=250 \mu \mathrm{m})$; and $(3)$ a higher magnification of the necrotic muscle showing the inclusion bodies (arrows) in the myofibrils ( $\mathrm{H} \& \mathrm{E}, \mathrm{bar}=50 \mu \mathrm{m})$. 

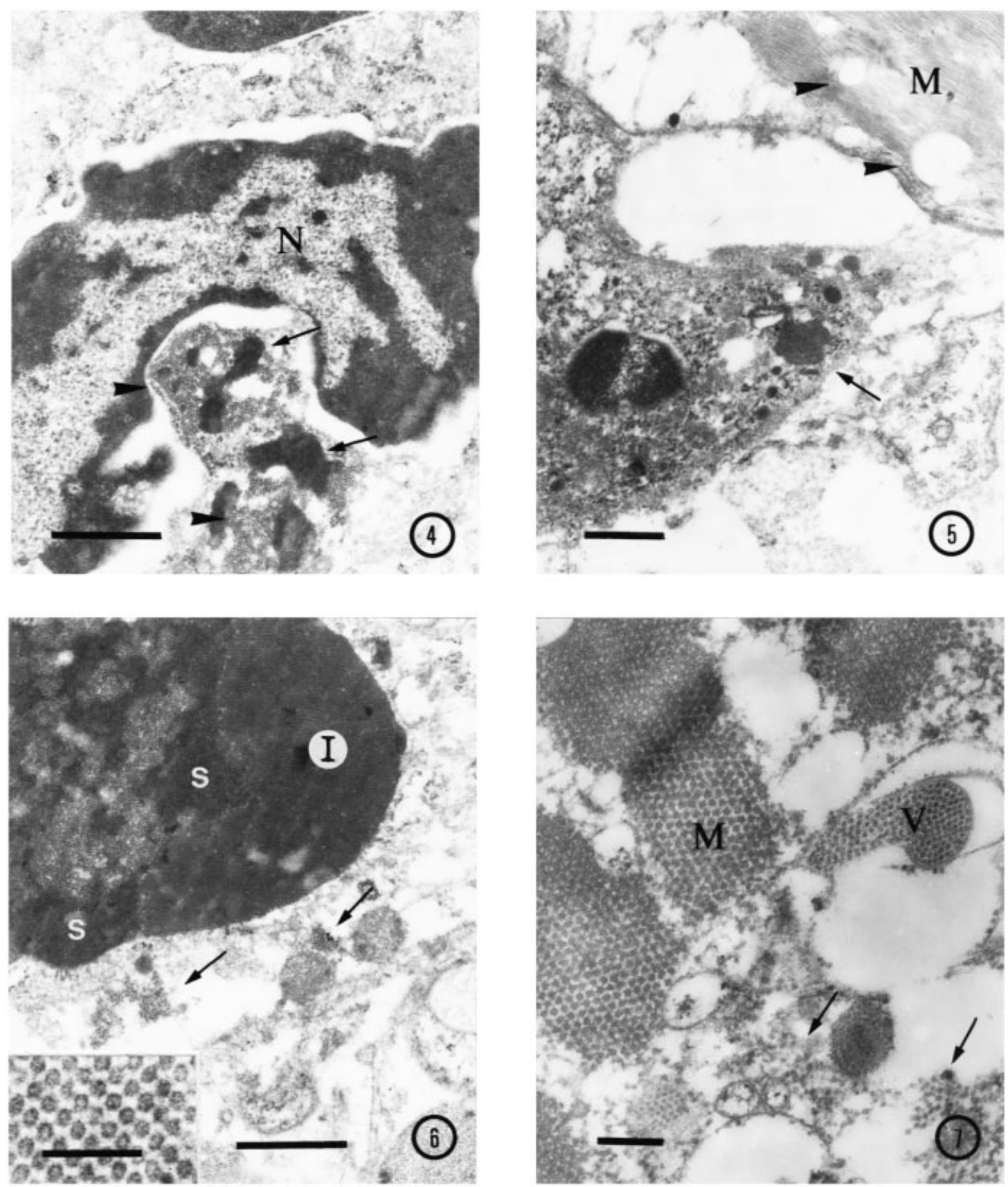

Figures 4-7 Transmission electron micrographs of Macrobrachium muscle virus (MMV) in the muscle of diseased prawn: (4) the MMV viruses (arrowheads) and virogenic stroma (arrows) aggregated in the cytoplasm ( $\mathrm{N}$ : nucleus; bar $=1 \mu \mathrm{m})$; (5) inclusion body (arrow) located in necrotic muscle tissue displaying vacuolation (arrowheads) (M: muscle; bar $=1 \mu \mathrm{m}$ ); (6) icosahedral virions arranged in the inclusion body (I) and free viral particles (arrows) (S: virogenic stroma; bar $=1 \mu \mathrm{m}$ ), (insert) high magnification of MMV viruses $(\mathrm{bar}=100 \mathrm{~nm}$ ); and $(7)$ the difference in size between the MMV $(\mathrm{V})$ and myofibre $(\mathrm{M})$ of giant freshwater prawn (arrows: free viral particles; bar $=250 \mathrm{~nm})$.

internal parasites were observed by light microscopy in necrotic muscle of affected prawns.

The clinical signs of the diseased prawns were similar to IMN syndrome, with the exceptional addition of dense cytoplasmic inclusion bodies in the affected muscle. In stained histological sections, 
Table 1 Comparison of Macrobrachium muscle virus (MMV) with known icosahedral viruses of shrimps and prawns

\begin{tabular}{|c|c|c|c|c|c|c|}
\hline Virus & Host & $\begin{array}{l}\text { Infected } \\
\text { tissues }\end{array}$ & $\begin{array}{l}\text { Average } \\
\text { diameter } \\
(\mathrm{nm})^{\star}\end{array}$ & $\begin{array}{l}\text { Location } \\
\text { of virus } †\end{array}$ & $\begin{array}{l}\text { Probable } \\
\text { classification }\end{array}$ & References \\
\hline IHHNV & $\begin{array}{l}\text { P. stylirostris } \\
\text { P. vannamei } \\
\text { P. monodon } \\
\text { P. semisulcatus }\end{array}$ & $\begin{array}{l}\text { Cuticular } \\
\text { epidermis, } \\
\text { connective tissue, } \\
\text { haematopoietic tissue, } \\
\text { gonads, gill }\end{array}$ & 22 & C & Parvo-like virus & $\begin{array}{l}\text { Lightner et al. } \\
\text { (1983) }\end{array}$ \\
\hline HPV & $\begin{array}{l}\text { P. semisulcatus } \\
\text { P. merguiensis } \\
\text { P. orientalis } \\
\text { P. esculentus } \\
\text { P. penicillatus }\end{array}$ & Hepatopancreas & $22-24$ & $\mathrm{~N}$ & Parvo-like virus & $\begin{array}{l}\text { Lightner \& } \\
\text { Redman } \\
\text { (1985) }\end{array}$ \\
\hline LPV & $\begin{array}{l}\text { P. monodon } \\
\text { P. merguiensis } \\
\text { P. esculentus }\end{array}$ & $\begin{array}{l}\text { Lymphoid } \\
\text { organ }\end{array}$ & $25-30$ & $\mathrm{~N}$ & Parvo-like virus & $\begin{array}{l}\text { Owens, Beer \& } \\
\text { Smith (1991) }\end{array}$ \\
\hline TSV & P. vannamei & $\begin{array}{l}\text { Cuticular } \\
\text { epithelium, } \\
\text { subcutis, muscle of } \\
\text { appendages, gill }\end{array}$ & $31-32$ & C & Picornavirus & $\begin{array}{l}\text { Lightner et al. } \\
\text { (1995) }\end{array}$ \\
\hline SMV & P. monodon & Gut & 20 & C & Parvo-like virus & $\begin{array}{l}\text { Fraser \& } \\
\text { Owens (1996) }\end{array}$ \\
\hline MHPV & M. rosenbergii & Hepatopancreas & 29 & $\mathrm{~N}$ & Parvo-like virus & $\begin{array}{l}\text { Anderson s } \\
\text { et al. }\end{array}$ \\
\hline MMV & $M$. rosenbergii & Muscle & 23 & C & Parvovirus or Picornavirus & Present paper \\
\hline
\end{tabular}

*Based on thin sections.

$\nmid \mathrm{N}$ : nucleus; C: cytoplasm.

the inclusion bodies were basophilic in $\mathrm{H} \& \mathrm{E}$ (Fig. 3), Feulgen positive, green in pyronin methyl green and yellow in acridine orange fluorescent. In spite of these histochemical reactions, it was sometimes difficult to distinguish inclusions from haemocyte nuclei. Using pryonin methyl green, the characteristically green-stained viral inclusions can be distinguished from haemocyte nuclei. Therefore, pyronin methyl green is recommended as a diagnostic tool for detection of MMV.

In the ultra-thin sections of the affected areas, viral particles were observed in the cytoplasm of infected muscle cells (Fig. 4). Large viral foci were typically scattered in the cytoplasm and occasionally formed crystalline arrays (Fig. 5). Near the nucleus, membrane-limited inclusions were sometimes associated with the virogenic stroma. The non-enveloped virions were icosahedral with a mean size of $22.9 \pm 3.6 \mathrm{~nm} \quad(n=20) \quad$ (Fig. 6). The myofibre (average size $=40-45 \mathrm{~nm}$ ) of the prawns could be ultrastructurally distinguished from virus particles by size (Fig. 7).

The morphological and histological alterations observed in the present study were similar to those previously described as idiopathic muscle necrosis (IMN) (Akiyama et al. 1982). Idiopathic muscle necrosis disease was characterized by non-transparent muscle in abdominal segments 3-6, while prawns affected by MMV displayed the same features but in abdominal segments 2-6. Furthermore, IMN occurred in Malaysian and Thai hatcheries at 19-21 days of age, while all prawns affected by MMV in southern Taiwan were more than 28 days of age.

Excluding the cytoplasmic inclusion bodies observed in the necrotic cells of MMV-diseased prawns, the same histological changes were noted in both MMV and IMN infections. As noted earlier, these changes were characterized by a progressive segmental myofibre degeneration and necrotic myopathy with numerous single, rows, aggregations and sheets of hyperchromatic myonuclei. Centrally or eccentrically placed (nuclear internalization) pyknotic nuclei were also frequently observed.

Macrobrachium muscle virus was compared with similarly shaped viruses of shrimps and prawns, as shown in Table 1 . Five out of the six identified viruses are found in penaeid shrimps, while one is 
found in freshwater prawns. In spite of the similar morphology of MMV with those of penaeid and prawn parvo-like viruses, it differs primarily in the target tissue (striated muscle). Although MHPV shares the same host with MMV, it is only found in the hepatopancreas and was demonstrated to be non-pathogenic (Anderson, Law, Shariff \& Nash 1990a). In addition to MMV, several viruses have been found intracellularly within the cytoplasm, including IHHNV, TSV and SMV, and of these, only IHHNV and TSV contain acidophilic inclusion bodies (Lightner, Redman \& Bell 1983; Lightner, Redman, Hasson \& Pantoja 1995); SMV does not form inclusion bodies (Fraser \& Owens 1996). Therefore, MMV virus can be distinguished from the other similar viruses by: (1) being found only in $M$ rosenbergii; (2) being found only in striated muscle; and (3) forming basophilic inclusions within the cytoplasm.

Future research on MMV should include: (1) the relationship between MMV and IMN; (2) purification to definitively characterize the virus; and (3) studies on the pathogenicity of MMV. The characteristic size, structure, absence of envelope and cytoplasmic localization of MMV suggest that the virus is closely related to the family Picornaviridae or Parvoviridae. The unique characterization of MMV among crustacean viruses is the reason the present authors tentatively name it Macrobrachium muscle virus (MMV) and suggest that this name should only be retained until its taxonomic position is ascertained.

\section{Acknowledgement}

This work was supported by the Council of Agriculture under Grant No. 88. AST-1.4-FID02-(2-1)

\section{References}

Akiyama D., Brock J.A. \& Haley S.R. (1982) Idiopathic muscle necrosis in the cultured freshwater prawn, Macrobrachium rosenbergii. Vetinary Medicine, Small Animal Clinician 77, 1119-1121.

Anderson I.G., Law A.T., Shariff M. \& Nash G. (1990a) A parvo-like virus in the giant freshwater prawn, Macrobrachium rosenbergii. Journal of Invertebrate Pathology 55, 447449.

Anderson I.G., Nash G. \& Shariff M. (1990b) Mass larval mortalities in the giant freshwater prawn, Macrobrachium rosenbergii de Man, cultured in Malaysian modified static 'green water' systems. Journal of Fish Diseases 13, 127-134.

Bell T.A. \& Lightner D.V. (1988) A Handbook of Normal Penaeid Shrimp Histology. World Aquaculture Society, Baton Rouge, LA.

Fraser C.A. \& Owens L. (1996) Spawner-isolated mortality virus from Australian Penaeus monodon. Diseases of Aquatic Organisms 27, 141-148.

Kurnick N.B. (1952) Histology staining with methyl greenpyronin. Stain Technology 27, 233-242.

Lightner D.V. \& Redman R.M. (1985) A parvo-like virus disease of penaeid shrimp. Journal of Invertebrate Pathology 45, 4753.

Lightner D.V., Redman R.M. \& Bell T.A. (1983) Infectious hypodermal and haematopoietic necrosis virus, a newly recognized virus disease of penaeid shrimp. Journal of Invertebrate Pathology 42, 62-70.

Lightner D.V., Redman R.M., Hasson K.W. \& Pantoja C.R. (1995) Taura syndrome in Penaeus vannamei (Crustacea: Decapoda): gross signs, histopathology and ultrastructure. Diseases of Aquatic Organisms 21, 53-59.

Nash G., Chinabut S. \& Limsuwan C. (1987) Idiopathic muscle necrosis in the freshwater prawn, Macrobrachium rosenbergii de Man, cultured in Thailand. Journal of Fish Diseases 10, 109-120.

Owens L., Beer S.D. \& Smith J. (1991) Lymphoidal parvoviruslike particles in Australian penaeid prawns. Diseases of Aquatic Organisms 11, 129-134. 